\title{
Inheriting Abraham: The Legacy of the Patriarch in Judaism, Christianity, and Islam, by Jon D. Levenson
}

Princeton: Princeton University Press, 20I2 | xvi + 244 pages | ISBN: 978-0-69I-I 5569-2 (hardcover) \$29.95 | ISBN: 978-0-69I-I6355-0 (softcover) \$19.95 | ISBN: 978-I-4008446I-6 (ebook)

This book, whose author is Professor of Jewish Stud-

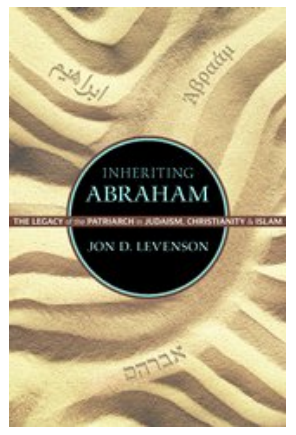
ies at Harvard University, provides an excellent introduction to Jewish interpretations of the biblical figure of Abraham and useful comparisons with Christian and Islamic interpretations. Along with this it raises serious and (in my view) appropriate questions about the contemporary effort to ground interfaith relations between Jews, Christians, and Muslims in the figure of Abraham/Ibrahim since he is common to all three traditions, something I will here call "Abrahamic ecumenism."

It is appropriate to begin with a survey of the book's content, highlighting what I find to be of particular interest, though this will not do justice to the variety of material covered or to the impressive argumentation with which it is handled. The introductory chapter discusses the nature of the Jewish traditions about Abraham, the complexity of their relation to the Christian and Islamic traditions and the impossibility, in the light of modern critical scholarship, of finding a "real" Abraham behind the diverse traditions. We must recognize the historical nature of the texts but we must also be open to the "transcendent and enduring religious messages" (I 7 ) they convey.

Chapter I explores Jewish and Christian texts to disprove the common stereotype that makes Judaism exclusivist and Christianity universalist. Chapter 2 explores events in the biblical account of Abraham, including his dealings with Lot, the births of Ishmael and Isaac, and the nature of the covenant. It notes particularly that many nations gain blessings from Abraham though the covenant is limited to his physical descendants through Isaac.

The Akeda (the "binding" of Isaac; Christians and Muslims speak of the "sacrifice" of Isaac or Ishmael) is dealt with in chapter 3. Among other things the author notes that while Jews, Christians and Muslims speak of the faith of Abraham the Bible speaks only of obedience, as a result of which the covenant is no longer purely a matter of grace since Abraham has now merited it. The place of the Akeda in the later Jewish traditions is discussed at length though, 
oddly, there is no mention of the claim in some of those traditions that Isaac was actually sacrificed, as publicized particularly by Shalom Spiegel in The Last Trial. This claim is, however, mentioned briefly as a possible but unlikely result of biblical criticism. Various Christian interpretations of the Akeda and the Qur'anic interpretation are then discussed. Finally the modern criticism of the Akeda as immoral, especially that of Kant, is discussed and the point is made that none of the three traditions as they have developed would permit the sacrifice of a son.

Chapter 4 deals with the stories of Abraham as aggressive monotheist and iconoclast, destroying his father's idols, in the later Jewish and the Islamic traditions, though not in Genesis and not in the Christian tradition. It also discusses the idea of Abraham as a kind of philosopher. Christians do not share the iconoclastic theme because of, the author suggests briefly, their more favourable attitude to icons. I would like to have seen a further exploration of this. Chapter 5 begins by exploring the later Jewish view that Abraham kept the commandments of the Torah before the time of Moses. It also explores the contrasting view of Paul that makes Abraham an exemplar of faith and mentions alternative Christian interpretations. Evidence is presented to show the inadequacy of the simplistic idea that Judaism is a religion of law and Christianity a religion of faith and creed.

The author's critique of Abrahamic universalism, which underlies the varied and complex discussions in the earlier chapters, is presented explicitly in chapter 6 . Efforts to make the figure of Abraham serve as a basis for the reconciliation of Jews, Christians and Muslims misconceives the biblical Abraham or privileges some of the three traditions over other(s). For example, Abraham may be considered as "father" of the three communities but Jews and Christians interpret this fatherhood in radically different ways and Muslims do not consider him "father" of their community. The contradictory interpretations of Abraham are such that to treat the three communities as equal violates essential claims of each of them. There is no neutral Abraham, and we must learn to appreciate the differences as well the commonalities among the traditions. Considerable space in this chapter is devoted to criticizing two books, Bruce Feiler's Abraham: a Journey to the Heart of Three Faiths and Karl-Josef Kuschel's Abraham: Sign of Hope for Jews, Christians and Muslims.

We should note that the subtitle of the book is something of a misnomer, for by far the largest part of the material is from the Jewish tradition, as the author explicitly states within the book. There is, however, considerable Christian, particularly Pauline, material and it is well handled. There is much less 
Islamic material and most of it is limited to the Qur'an, though the points made are valid. The book almost calls for two complementary volumes, dealing in comparable depth and detail with the other two traditions.

There is a certain amount of apologetics in this book, or perhaps it is more accurate to say that the author provides a scholarly treatment of recognized apologetic themes. One example is the issue of universalism. At several points the author presents material that supports the argument that while the Jewish covenant is exclusive to Jews salvation is by no means limited to them, while, on the other hand, Christians and Muslims seek to draw in all people but have traditionally excluded from salvation those who do not come in.

Although himself a critical scholar, the author strongly privileges tradition. Scripture is always to be read in the light of the continuing tradition, as Jews have regularly done, and at several points he criticizes the Protestant sola scriptura approach (he avoids, appropriately, the term "fundamentalist"). In a sense, though, he violates this position by dealing with Islam almost entirely in terms of the Qur'an and, somewhat less so, by focussing mainly on Paul and early Christianity. Likewise, he shows little sympathy for radical modernist revisions of the traditions, of which Abrahamic ecumenism is a fairly extreme example. In his view it involves the creation of a new Abraham, who never existed, either in the Bible or in any tradition. It is not the path to take. The author certainly does not reject ecumenism but neither does he indicate what path he thinks it should take. Perhaps there is a clue toward the end of chapter 6 in his relatively favourable treatment of Louis Massignon, whom he sees as one of the authors of Abrahamic ecumenism. Massignon remained a firm Catholic but also found in Islam a revelation of God complementary to the Catholic revelation. The author doubts Massignon resolved the conflicting truth claims of the two religions, but he appreciates Massignon's effort to respect the integrity of both traditions. Any ecumenism that the author would support would have to have this characteristic.

In my view the manner in which Levenson makes tradition his benchmark leads him to underestimate the capacity of religions to change legitimately in the future, as they have in the past. One may ask whether the creation of a new Abraham is necessarily a bad thing, especially since he has been recreated so often in the past, as the author demonstrates so well. As it is, he does not go beyond a negative criticism of Abrahamic ecumenicism.

Still, that criticism is necessary and I see this book as "must" reading for anyone involved significantly in Abrahamic ecumenism since it provides a wake-up call to often unrecognised challenges facing this movement. Be- 
yond that, it will be of value to anyone interested in figure of Abraham or in scriptural religion as such, since it provides an excellent introduction to traditional Jewish approaches both to Abraham and to scripture generally.

\author{
William Shepard \\ University of Canterbury \\ (Retired)
}

